\title{
ARE THERE DEPENDABLE RULES OF CAUSATION?'
}

\section{LEON GREEN}

\section{Causal Relation}

The cases involving "cause" problems are multiple, but may be classified for the purpose of this discussion into two types. The simplest type assumes, first, that the defendant has done something; second, that another person has suffered some hurt; and third, that the defendant is responsible, if there is causal relation between the defendant's conduct and the other's hurt. This relation between conduct and hurt must be found in all cases, whether classified as crime, tort or otherwise. It arises in many forms.

Did $X$ die from a potion administered by $D$, by suicide, or from some disease? ${ }^{2}$

The defendant shot a gun. $A$ also shot a gun. $X$ has a wound. Did $D^{\prime} s$ shot give the wound ? ${ }^{3}$

Was the deceased's death due to a fall or to appendicitis or to cancer ? ${ }^{4}$

Did the deceased die of heart disease or an electric shock? Did the plaintiff's child die from burns or pneumonia? 5

$D$ 's servant put $X$ out of a conveyance at the foot of a hill. $X$ climbed the hill and entered her house, where she collapsed and

'This paper was read and discussed at the round-table on "Wrongs" held at the meeting of the Association of American Law Schools, December 28, I928. The subject of the discussion was: "Differences, if any, between the rules of causation in crime and in torts."

${ }^{2}$ Yaggle v. Allen, 24 App. Div. 594, 48 N. Y. Supp. 827 (1898); Walden v. Bankers' Life Ass'n, 89 Neb. 546, I3I N. W. 962 (I9II).

'Oliver v. Miles, 1 10 So. 666 (Miss. 1927), discussed in (1927) $27 \mathrm{Coz}$ L. REv. 754. The defendants $X$ and $Y$, while hunting together, fired simultaneously across a public highway. The plaintiff was struck by one of the shots, but he did not know which one. Wilson v. State, 24 S. W. 409 (Tex. Cr. App. I893).

-Aetna Life Ins. Co. v. Wicker, 240 Fed. 398 (C. C. A. 2d, 19r7) ; Ashelby v. Traveler's Ins. Co., I3I Minn. I44, I54 N. W. 946 (I9I5); Abendroth v. Fidelity \& Deposit Co., 73 Ind. App. 50, 124 N. E. 714 (1919).

${ }^{5}$ Robinson v. Western States Gas \& Electric Co., I84 Cal. 40 , 194 Pac. 39 (1920) ; Longuy v. La Society, etc., 52 Cal. App. 370, I98 Pac. IOII (I92I).

(6or) 
died. Did $D$ 's conduct in putting her out at the foot of the hill play a material part in her death ? ${ }^{6}$

$D$ 's street car was roughly handled. $P$ fell and bumped his head. Seven months later he suffered a stroke of paralysis. Did the rough handling of the car have an appreciable part in the paralysis? ${ }^{7}$

The defendant railway cut a telephone line so that the plaintiff was unable to get the doctor to attend his wife. Was the cutting of the wire a material factor in causing the wife's death? ${ }^{8}$

$D$ 's conductor sent $X$ back to remedy a hot box. Without warning $X$, the conductor gave orders to start the train. Later $X$ was found dead near the track with his limbs severed. Did the conductor's starting the train without warning have a substantial part in causing $X^{\prime}$ 's death? ${ }^{9}$

$X$ drank milk and ate beans, ${ }^{10}$ and within a few hours developed poisoning. Did the milk or beans poison him?

Did the plaintiff rely upon the representations of the defendant, or upon his own investigation, in giving credit to $X ?^{11}$

Was the plaintiff's loss of health a result of the slanderous statements made by the defendant? ${ }^{12}$

This type of case can be varied infinitely, first, in the conduct on $D$ 's part; second, in the combination with the conduct of other persons, and third, in the results. But so long as the inquiry is

- Tullgren v. Amoskeag Mfg. Co., 82 N. H. 268, r33 Atl. 4 (1926).

` Bishop v. St. Paul City Ry., 48 Minn. 26, 50 N. W. 927 (I892) ; Benson v. Altoona \& Logan Valley Electric Ry., $228 \mathrm{~Pa}$. 290, 77 Atl. 492 (I9ro).

${ }^{8}$ Hodges v. Virginia-Carolina Ry., I79 N. C. 566, 103 S. E. 145, 10 A. L. R. 1452 (I920).

- Moores v. Northern Pac. Ry., I08 Minn. I00, 121 N. W. 392 (1909) ; Nealis v. C. R. I. \& P. Ry., 218 N. W. I25 (Minn. I928); Kapuscianski v. Phila. \& R. C. \& I. Co., 289 Pa. 388, I37 Atl. 619 (I927).

${ }^{10}$ Buell v. Kansas City Life Ins. Co., 250 Pac. 635 (N. M. I926) ; Newsoms v. Commercial Casualty Ins. Co., I 47 Va $47 \mathrm{I}, \mathrm{I}_{37} \mathrm{~S}$.'E. 456,52 A. L. R. 363 (I927). For similar inquiries: Ginsberg v. Wabash Ry., 219 Mich. 665, I89 N. W. 1018,28 A. L. R. 518 (I922); Wunsewich v. Olsen, I37 Minn. 98,162 N. W. I054, 2 A. L. R. 560 (I9I7); Hiatt v. Travelers Ins. Co., I97 Iowa 153, I97 N. W. 3,33 A. L. R. 655 (1924).

II Addington v. Allen, II Wend. 375 (N. Y. I833); Fottler v. Mosely, 179 Mass. 295,60 N. E. 788 (Ig0r), aff'd, I85 Mass. 563 , 70 N. E. 1040 (1904); other cases cited in BoHLEN, CASES ON TORTS (2d ed. 1925) 763.

${ }^{12}$ Terwilliger v. Wands, 17 N. Y. 54 (1858), BoHLEN, op. cit. supra note II, at 792; Comment (I928) 36 Y YLE L. J. II48. 
whether $D$ 's conduct played a part, or a material part, in producing the hurt which supplies the subject of investigation, the question is relatively simple. Even here the absence of data, the multiplication of data, or the obscurity of the available data, may make the problem a difficult one. But the difficulties are those common to all proof, and they may arise on the same facts in a criminal prosecution, in an action for negligence, and on a policy of insurance. Every sort of data which will support an inference in other situations may be availed of here, but probably the expert is called upon more frequently to trace the workings of cause and effect than in any other type of case. ${ }^{13}$ But assuming that there is some proof made, the weight to be given to the evidence requires the judge to exercise his normal function of saying whether there is a basis for two reasonable judgments. If there is not, the case ends for failure of proof to show causal relation. But if the proof is sufficient, the case will be sent to the jury. In criminal cases the court will require the jury to believe beyond a reasonable doubt before a finding is made against the defendant, while in most jurisdictions in tort cases the jury may base their finding on a preponderance of the evidence.

These are not the problems of "causation" which afford the difficulties courts talk about under that head. An examination of the current case books on criminal law and torts discloses few cases under that heading which present a problem of this type. These cases are not even digested separately but are found scattered here and there under many headings. As a problem of causation its treatment is largely incidental. It is not what caused the hurt, but was the defendant's conduct a factor in producing the hurt. Jeremiah Smith's "substantial factor" ${ }^{14}$ phrase, sometimes stated as a "material," 15 or "appreciable" 16 factor, puts the

${ }^{23}$ State v. Elftman, I16 Kan. 2I4, 226 Pac. 795 (I924); Wilson v. State, 195 Ala. 675, 71 So. I15 (I916); State v. Price, I35 Minn. I59, I6o N. W. 677 (1916); Murray v. U. S., 288 Fed. 1008 (Ct. of App. D. C. 1923); and supra notes $2,4,5,6,7$ and to.

${ }^{13}$ Smith, Legal Cause in Action of Tort (1912) 25 HARv. L. REv. 103, 223, 305, Selected Essays on Torts (1924) 649, 7II, 7I2.

${ }^{15}$ Anderson v. Minneapolis, St. P. \& S. Ste. Marie Ry., I46 Minn. 430, I79 N. W. 45 (I920); Wilson v. State, supra note I3; Green, Rationale of ProxiMATE CAUSE (I927) I34.

${ }^{10}$ Sellers v. Reice Construction Co., 124 Kan. 550, 262 Pac. 19 (1927). 
problem aptly enough, but it affords no answer. The answer is only to be had in the judgment of the particular tribunal, whether judge or jury, to which the problem is allocated by the judicial process. But it will be noted that neither this phrase nor its synonyms cramp judgment. It is one of the easiest inquiries courts have to make. No rules of law aside from the general rules of procedure are required and none could be found if they were sought. Each case calls for a fresh judgment.

But it is remarkable to what extent confusion arises even in dealing with this relatively simple problem. It is repeatedly insisted that there must be something further by which to measure this "substantial factor," or that it is merely the "causa sine qua non," "but for," or some other test in disguise. This attitude indicates the failure to appreciate the purpose for which the formula is used, and thus its whole significance is lost.

The inquiry here involved is causal relation between the defendant's conduct and the plaintiff's hurt. It can be stated in several ways, such as physical cause, or scientific cause, or cause and effect, or otherwise. The idea is the same in all of these. Causal relation presents a jury question if an issue at all. Thus it is said to be a matter of "fact." Ordinarily it is so clear that the question should not be submitted. Nevertheless courts do submit it in nearly all cases, and since such practice is seldom hurtful, I make no point of the uselessness of submitting the issue. But when the issue is submitted, whether necessary or not, it should be submitted sensibly. The judge's functions at this point are two: (I) to determine whether the evidence raises an issue, and (2) to submit the issue. It is for the last purpose only that the formula suggested has any function to perform. For that function it is useful. It is simple; it calls the attention of the jury to the question on which a jury's judgment is desired; it does not mislead the jury. It thus serves the function for which it is designed, however modest that may seem. Unless the narrowness of the point is constantly kept in mind, this formula cannot be dealt with intelligently.

For such a purpose the "sine qua non" formula would be too scholastic unless translated. But the larger objection is that no 
reliance can be placed upon it. It falls down in the multiple cause cases $^{17}$ (which, as a matter of fact, include all cases), as well as in the successive cause cases. ${ }^{18}$ In no case does it present the issue to be determined. It sends the inquirer back to discover if the result could have happened without the defendant's participation. The assumption is that if the result would have happened anyhow, then the defendant is not a cause. Such an inquiry at this point is vicious from two aspects: ( $I$ ) it presents an inquiry impossible of determination; the case is not what might have happened but what has happened; (2) the inquiry while stated in what seems to be terms of cause is in fact whether the defendant should be held responsible. ${ }^{19}$ Hence this formula does not present the simple inquiry as to whether the defendant's conduct was $a$ factor in the result. The latter is the subject pertinent at this stage, and while it may not always be simple, inasmuch as it calls for a capacity to measure the effects of a multitude of factors which are found in most cases, still, out of the many things that must be done in fixing responsibility as a whole, it is possibly the detail that can be done best. And this is true even though it may be conceded that quantitative measuring can never be definitely or accurately done in such matters. Our every-day existence in a thousand different ways depends upon this very capacity, and most people are capable of making very good guesses where the ordinary affairs of life are involved. The formula of Jeremiah Smith merely focuses attention on the fact that measuring must be done at this point. The judicial process, as developed through the common law, requires that such be done. The function has been allocated to the jury. So long as the jury keeps within the procedural rules, its judgment on the question is final. That is the method by which such questions are settled and there is nothing more to be said. If any other method had been adopted, there would have been the same necessity for reaching a stage of finality. But at what point judgment will fall in the particular case cannot

It Infra notes 22, 23, 24, and 43.

${ }^{28}$ Illinois Cent. Ry. v. Wright, I35 Miss. 435, I00 So. I (1924); Douglas, etc., Co. v. Tex. \& P. Ry., I50 La. I038, 91 So. 503 (I922).

${ }^{10}$ GreEN, op. cit. supra note 15 , at 167-170. 
be anticipated, nor can it be controlled by rules or formulas. The process leaves the jury free-and the freer the better-to give its judgment, and whether the world at large agrees or not is wholly immaterial. Government having allocated the power to pass judgment to the jury, all that judges and legal scholars can do is to formulate adaptable phrases for passing the problem to the jury. There is no reason why any other phrase which can perform this function should not be used. While uniformity of expression accelerates administration, an insistence upon too great uniformity does the other thing.

It may be suggested that sometimes judges try cases without juries. But in such cases judges, although they are in fact laymen as to this sort of question, do not spend any time charging themselves. But assuming that they employ for their own thinking the same formulas which they use for instructing juries, the "substantial factor" formula will present the question to them as aptly as to a jury. However it does not make judgment automatic. They, as a jury, exercise their power of judgment and that is the end of it for that case, always excepting the power of an appellate court to do the contrary if it takes another view of the matter. As in the case of a juiry, there is no way to anticipate or control the judgment of the judge. Thus I would conclude as to this type of causation that, while no rules are possible, there is a necessity for the formulation of adaptable phrases for use in passing to a jury the questions they must decide. It is a problem in the use of language. Uniformity of expression is desirable so long as it is not insisted upon to the extent of inflexible ritual.

What I have said so far is no more than well-recognized legal theory. It is the method we should like to follow in trying cases. As a matter of fact, when a case is submitted to a jury, however clearly marked may be the issues which the jury are supposed to answer, I have always felt that in most instances they give their answer on the whole case. Full recognition of this fact is given, and allowance made for it in negligence cases, in the formula devised for submitting the negligence issue to the jury. The "reasonable care under the circumstances" formula gives a jury the 
widest latitude for considering the whole case. ${ }^{20}$ Nor do I object, for after all it is the judgment of laymen on the whole case that organized society desires. But there is nothing to be gained in giving the jury the same latitude a second time under the causation issue. The latter issue is much narrower than the negligence issue and calls for a different sort of judgment. The determination of negligence requires a judgment on all of the factors which we sum up under "policy." But causal relation calls for "scientific fact." There is no simpler way to express the latter than to call it "causal relation"; and there is no simpler way to submit it to a jury than through a formula calling upon the jury to say if there is any "material," or "substantial," or "appreciable" connection between the defendant's conduct and the plaintiff's hurt. There is extremely little work for such a formula to do, for normally causal relation is so clear that a judge would not be warranted in submitting it to a jury. The major defect in present practice is that judges do not recognize what a narrow problem causal relation is, and in almost every case submit some other problem which should not be submitted to a jury at all, or submit the negligence issue a second time, under a supposedly "proximate cause" formula. The latter formula is in reality nothing more than the negligence formula stated a little differently.

\section{Limitations Upon Responsibility in Terms of "Proximate CAUSE"}

Along with the type just considered is frequently found another kind of problem of the greatest difficulty which the courts treat also as a "cause" question. This is known by many names, but is probably best known as "proximate" or "legal" cause. It will be noted that the mere statement of a case involving a "cause" problem of the latter sort eliminates any question of causal relation in the sense first discussed. Causal relation must be assumed in these cases, or there is nothing further to talk about. The problems

${ }^{20}$ See my article, The Negligence Issue (1928) 37 Y ALE L. J. 1029; also my article, The Duty Problem in Negligence Cases (1928) 28 CoL. L. REv. Ior4, I023, I030. There is much yet to be done in developing the process for allocating functions to judge and jury in the particular case. In my article, $A N e w$ Development in Jury Trial (I927) I3 A. B. A. J. 715, I attempted to outline the progress made in this direction in three states. 
dealt with under "proximate causation" involve limitations upon legal responsibility or legal protection-the phase of legal theory concerned with rights and duties. They are the same problems as are involved in statutory construction, interpretation of contracts, in the employment of assumed risk and contributory negligence as defenses, and in the great host of privileges found in defamation as well as in the interferences with the relations existing between other persons. Many of the hardest problems involved in ascertaining the protection given under the statutes dealing with homicide, in determining the scope of accident policies and other contracts, and especially the scope of protection afforded under the broad common law rules of torts, are dealt with in terms of proximateness and its opposite-remoteness. Various type situations have developed their own terminology, and, due to our fragmentary and helter-skelter legal theory, any difficult question can be readily translated into at least several of these phrase networks. A court is seldom limited to a single choice. It does not seem that this idea is widely appreciated in view of many of the debates about conflicting legal doctrines. ${ }^{21}$ But once it is recognized, many of the seeming paradoxes in legal theory disappear completely. That the difficulties which arise in negligence cases, for example out of distinctions between contributory negligence and assumed risk, are of this sort would probably be readily conceded. It is equally so as to contributory negligence and proximate cause, last clear chance, wilful and gross negligence, and other phrases used in these cases. Likewise in deceit cases there are various sorts of false statements, material statements, and statements of opinion and fact, and other such terms. In defamation, libelous, slanderous, privileged statements, privileged occasions, malice, fair comment, truth, and others, supply another group of highly expansible and interchangeable phrases for the cases classified under that heading. Every group of cases has its own set up of phrases. And what is more, it will be found that each court, if not each judge and each lawyer, although using the same words, will differ from case to case in the method of identifying through these phrases the questions on

21 The idea is worthy of much fuller elaboration than can be given here. 
which judgment is to be passed. In a negligence case, for instance, one judge will identify the question as one of negligence, while another will insist that it is one of legal duty or of contributory negligence, or assumption of risk, or proximate cause, or mitigation of damages, or last clear chance, or what not. Much confusion can be accounted for by a recognition of the fact that all words are not the same to all people. Nevertheless, most of us are constantly contending that someone else is wrong and we are right in the use of terms, as if there could be a right and a wrong in such matters. Convenience is at a high premium in these matters, but to require of the use of language, and of individual judgment as well, a Ioo per cent perfection (agreement), is to place one's self along with the Ioo per centers of other sorts. Even the smallest and most aptly chosen network of words (a statute), for the simplest and most kindred cases, almost invariably develops niceties which multiply so long as courts attempt to rest judgments upon the shadings of the words used. Language is just one of the numerous factors which should and ordinarily do control judgment, and the weight that should be given it is as variable as that given to any other factor. Legal science has much to gain from recognizing that problems for judges and juries can be stated in multiple forms, and that whatever form adapts itself to the demands of the particular court or particular problem is the best for the time and place. Such an attitude takes a great deal of the emphasis away from rules and doctrines, and places it on intelligent communication. It distributes the strain now placed upon stereotyped terminology over an entire vocabulary. If I may use an exaggerated but strikingly accurate figure to illustrate the point, I should say that lawyers, scholars and judges frequently broadcast the same subject-matter but on different wave lengths. It requires highly selective receiving apparatus to eliminate the interference caused by the crowding. The problem may be to thin out the stations and promote the organization of systems on a large scale, but it certainly is not to reduce all broadcasting for all problems and all courts and all lawyers to a single system. For a beginning, I have long advocated the elimination of the "proximate" and "legal cause" network. It has 
sought to preëmpt wave lengths already in use; it interferes with too many better equipped stations; the service it attempts to render can better be handled from other points.

Several of the groups of cases which are both torts and crimes and which are dealt with in the phraseology of proximate cause are quickly passed in review. Take the case of $X$ who has been given a mortal hurt by the defendant, but is later given a second fatal hurt by another person,,$^{22}$ or by himself, ${ }^{23}$ or by the treatment of a surgeon or physician. ${ }^{24}$ In these cases there is no question of causal relation between the defendant's conduct and the death. The defendant's conduct was at least one of the material cause factors. Nor do the courts think otherwise. But does such conduct of the defendant amount to murder? In the case of a second fatal hurt by another person who may also have attempted to kill $X$, the North Carolina and Vermont courts hold that the first blow is not murder because the same men cannot be killed twice. ${ }^{25}$ They stick in the meaning of the word "killed" as it is found in the statute. In construing the statute, they are guided solely by the words used, ignoring its purpose and other factors. I have found no tort case quite so narrow. But other courts would hold both the first and second assailant for murder, inasmuch as both clearly contributed to the death, although the hurt given by either would have been sufficient as a cause factor. The courts, in all sorts of cases, agree that the defendant does not escape responsibility because death is hastened by surgical or medical treatment. ${ }^{26}$

2 State v. Scates, 50 N. C. $420^{\circ}$ (1858) ; People v. Fowler, 178 Cal. 657, I74 Pac. 892 (Igi8), Sayre, Cases on Criminal Law (1927) I83; People v. Ah Fat, 48 Cal. 6i (1874), Beale, Cases on Criminal Law (2d ed. ig07) 340; State v. Wood, 53 Vt. 560 (I88r).

${ }^{23}$ People v. Lewis, I24 Cal. 55I, 57 Pac. 470, 45 L. R. A. 783 (1899), SAYRe, op. cit. supra note 22, at 189, MrkeII, Cases on CRIMINAL LAW (2d ed. 1925) 468.

24 People v. Cook, 39 Mich. 236 (1878), BeALE, op. cit. supra note 22, at 34I ; Thompson v. L. \& N. R. R., 9 I Ala. 496 , 8 So. 406 , II L. R. A. I46 (I890).

${ }^{2}$ State v. Wood, State v. Scates, both supra note 22 . The same problem is involved in such cases as Taylor v. State, $4 \mathrm{I}$ Tex. Cr. App. 564, 55 S. W. 961 (1900), MIKELI, op. cit. supra note 23, at 473 ; Comm. v. Campbell, 7 Allen $54 \mathrm{I}$ (Mass. I863), BEALE, op, cit. supra note 22 , at 350 .

* Regina v. Davis \& Wagstaffe, I5 Cox C. C. I74 (I883), SAYre, op. cit. stipra note 22, at I85, BEALE, op. cit. supra note 22, at 333 ; People $v$. Townsend, 214 Mich. 267, 183 N. W. 177, I6 A. L. R. 902 (1921); Sauter v. N. Y. C. \& H. R. R., 66 N. Y. 50 (I876); Note (I920) 8 A. L. R. 5 I6 (particularly the 
The case of the serious though not fatal wound, followed by some risk incident to treatment or other hurt, from which the injured person dies, gives greater difficulty. How far is responsibility extended in these cases? Causal relation is seldom doubtful in them and for all practical purposes it may be forgotten. So far as the giver of the first hurt is concerned, the problem is to discover what protection will be afforded the injured person against the risks which follow in the wake of the first hurt. The ordinary risks, as those arising from anæsthetics, ${ }^{27}$ mistaken diagnosis, ${ }^{28}$ infections, ${ }^{29}$ self-inflicted hurts in delirium, ${ }^{30}$ and many others, ${ }^{31}$ are usually placed on the defendant. But the limits are rather quickly reached. If the injured person in the course of his treatment contracts some other disease, as scarlet fever, ${ }^{32}$ develops cancer, ${ }^{33}$ or becomes insane, ${ }^{34}$ or the physician or nurse makes a very extreme mistake, ${ }^{35}$ responsibility is frequently denied. Rules of any validity cannot be formulated here. Each case is too much its own. The courts attempt to use the foreseeability, or the nat-

modification made under the Texas Penal Code as shown by cases cited at 521); Barrow v. State, I88 Pac. 35I, 9 A. L. R. 207 (Okla. I920) ; Notes (I925) 39 A. L. R. I268; (1914) 5I L. R. A. (N. S.) 877.

${ }^{n}$ Rettig v. Fifth Ave. Trans. Co., 26 N. Y. Supp. 896 (1893) (death from shock). Contra: Mella v. Northern S.S. Co., I62 Fed. 499 (C. C. S. D. N. Y. I908).

${ }^{28}$ McGarrahan v. N. Y. N. H. \& H. R. R., I7I Mass. 2II, 50 N. E. 610 (I8g8); State v. Daly, 2ro Mo. 664, I09 S. W. 53 (1908); Note (I914) 48 L. R. A. (N. S.) II6.

${ }^{20}$ Armstrong v. Montgomery St. Ry., I23 Ala. 233, 26 So. 349 (I891) ; Dickson v. Hollister, $123 \mathrm{~Pa}$ 421, I6 Atl. 484 (1889) ; Sullivan v. Boston Elevated Ry., I85 Mass. 602, gI N. E. 90 (I904); O'Quinn v.aAlston, 213 Ala. 346, 104 So. 653,39 A. L. R. 126 (1925).

${ }^{30}$ Postal Tel. Cable Co. v. Hulsey, I32 Ala. 444, 3I So. 527 (Igor); Daniels v. N. Y. N. H. \& H. R. R., I83 Mass. 393, 67 N. E. 424 (Ig03).

an Baltimore City Pass. Ry. v. Kemp, 6I Md. 74, aff'd, 6I9 (1883); Wallace v. Penna. R. R., 222 Pa, 556, 71 Atl. 1086 (1909); Hirte v. Eastern WVis. Ry. \& Light Co., 127 Wis. 230, 106 N. W. 1068 (I906); Notes (1914) 48 L. R. A. (N. S.) 93; (I920) 8 A. L. R. 506, et seq.

${ }^{32}$ Bush v. Comm., 78 Ky. 268 (I880), BEALE, op. cit. supra note 22 , at 342 .

${ }^{*}$ Allison v. Fredericksburg, II2 Va. 243, 7I S. E. 525 (I9II), 48 L. R. A. (N. s.) 93 (1914).

s Scheffer v. Washington City, etc., R. R., 105 U. S. 249 (I88I) ; Salsedo v. Palmer, 278 Fed. 92 (C. C. A. 2d, I92I), 23 A. L. R. 1262 (1923); cf. Gasperin v. Consolidation Coal Co., I43 Atl. I87 (Pa. I928) (workmen's compensation case).

${ }^{35}$ Purchase v. Seelye, 23I Mass. 434, I2I N. E. 4I3 (1918), 8 A. L. R. 503 (I920). But see Wagner v. Mittendorf, 232 N. Y. 481, 484, I34 N. E. 539, 540, 20 A. L. R. 520 (I922). 
ural and probable consequence test-a supposedly proximate cause formula-in both civil and criminal cases. This formula, for use elsewhere than as part of the technic for submitting a question of negligence to a jury, ${ }^{36}$ would be beneath honest discussion were it not taken so seriously by many courts. It seems to be overlooked by those who put great faith in this formula that "proximateness" as a test of liability becomes, in turn, a major subject for determination. To determine "proximateness," therefore, we must have "probability." But "probability" itself must be determined, hence we employ "foreseeability" for that purpose. But "foreseeability" also must be determined, so we introduce the "ordinary prudent person." But he must be defined and oriented by the "circumstances of the particular case" before he can do his work. Thus each test must in turn have its own test until the question to be decided becomes completely obscured. Nothing more is done under this formula, as used at this point, than to state in the crudest fashion the question of responsibility or no responsibility. It is a very poor way of saying that somebody must pass judgment on the case. Whoever that somebody may be, trial court, jury, or appellate court, he will "foresee" as far as, and no further than, his own intelligence permits him. But this constantly expanding extravagant rigamarole about proximate cause and probable consequences has apparently so ensnared most judges that they have surrendered their independent power of judgment to it, in so far as that can be done while still leaving them able to reach a decision in the particular case. It is true that, under enlightened use, this formula need not get in the way, as it can be stretched to cover any end desired; but, on the other hand, it is subject to much abuse and may divert attention so widely from the problem involved that it has become one of the most hurtful influences in tort law. Both its vice and its virtue lie in the fact that it may count for anything or for nothing. Its function is similar to that of a joker in the game of poker.

In cases of minor hurts the extent of responsibility is still more strictly guarded. Courts do not relieve defendants from all

${ }^{36}$ Green, The Negligence Issue (1928) 37 Y ALE L. J. 1028. 
the incidents of treatment and infections, ${ }^{37}$ but in most instances they do from the serious ones, as well as from other risks, although causal relation is perfectly clear. ${ }^{38}$ The field is open here, as in cases of more serious hurts, and there is no possibility of stating rules which will give judgment much guidance in deciding these cases.

In the type of case in which death or other physical hurt is produced by fright, responsibility again falls far short of causal relation, so that it gives no trouble. But in which of these cases responsibility shall be imposed is not readily determinable. If the defendant is engaged in committing a serious crime, as an assault, and a third party is frightened to death by the violent manner of the assault, such has been held to be the basis for manslaughter. ${ }^{39}$ A recent Tennessee case is most interesting. The defendant, in order to frighten the occupants of a canoe, shot in the water near it. One man jumped out and in doing so overturned the canoe. Two men drowned. The defendant was held guilty of manslaughter. ${ }^{40}$ Likewise in most jurisdictions recoveries are allowed in tort for physical hurts received through fright. At least any difficulty from a question of causal relation has been eliminated in these cases. ${ }^{41}$ But the courts have not gone very far. ${ }^{42}$ Once it is recognized that a defendant may be held responsible criminally and civilly for hurts done through fright or other emotional dis-

${ }^{2}$ Examine: People v. Kane, 213 N. Y. 260 , 107 N. E. 655, L. R. A. 1915F 607 (I915); Tibbs v. Comm., 138 Ky. 558, 128 S. W. 871,28 L. R. A. (N. S.) 665 (I910); Note (1920) 8 A. L. R. 520.

${ }^{2}$ The limitations placed on responsibility by the doctrine of contributory negligence play a large part here. Note (IgI4) $48 \mathrm{~L}$. R. A. (N. s.) I08.

*In re Heigho, I8 Idaho 566, I1o Pac I029 (I9Io), 32 L. R. A. (N. S.) 877 (19II), SAYre, op. cit. supro note 22, at I99; Regina v. Towers, 12 Cox C. C. 530 (I874), BEAIE, op. cit. supra note 22, at 295, MrKeI, op. cit. supra note 23, at 460 .

${ }^{10}$ Letner v. State, 156 Tenn. 68, 299 S. W. 1049, 55 A. L. R. 915 (1927) ; cf. People v. Rockwell, 39 Mich. 503 (I878) (deceased knocked down by defendant and then stepped on or kicked by horse).

"Bohlen, Right to Recover for Injury Resulting from Negligence without Impact (I902) 50 AMr. L. REG. I4I ; Goodrich, Emotional Disturbances as Legal Damage (1922) 20 Micr. L. REv. 497; Throckmorton, Damages for Fright (1921) 34 Harv. L. Rev. 260, Selected Essays on Torts (1924) 303; Green, The Duty Problem in Negligence Cases (I928) 28 CoL. L. Rev. IoI4.

${ }^{2}$ Comm. v. Couch, 32 Ky. 638, 106 S. W. 830, 16 L. R. A. (N. S.) 327 (1908). But cf. St. Louis S. W. Ry. v. Alexander, I06 Tex. 518, 172 S. W. 709 (1915); Nelson v. Crawford, I22 Mich. 466, 8I N. W. 335 (1899); (1927) 36 YAIE L. J. II 48 ; (I928) 38 Y ALE L. J. 68. 
turbance, rules have done about all they can to control the judgments of judges and juries in the particular case. Rules of proximateness, remoteness, or foreseeability, as elsewhere, do more to confuse than they do to clarify. The more simply the problem can be stated, the more intelligent the judgment, and probably also the more acceptable.

Another group of causation cases in which causal relation is clear, but responsibility is not, includes the "nuisance cases." The defendant maintained a pig pen, but its odor alone was not a nuisance except in combination with the odors from his neighbors' pens. ${ }^{43}$ In another case the defendant's mine discharged refuse into a small creek. Many other mines did the same in other small creeks. A landowner on a river below the conjunction of these several creeks was injured by the deposits of this refuse on his land. There are some very important cases of this class, in which the plaintiffs have been denied recovery against a single defendant because it could not be shown to what part of the harm his conduct contributed. ${ }^{44}$ It is clear that the defendant's conduct was a material factor in the result, but to what extent cannot be shown. Nor do all courts stop to find out the extent of contribution so long as it is appreciable. ${ }^{45}$ Some one must bear the risk. Must it be the plaintiff who cannot single out any defendant quantitatively, or must the risk be placed on any one or more whom the plaintiff may sue? In criminal cases the courts consistently find for the defendant. But should that be so civilly? Or is a generalization desirable here either way? Should not the case be deliberately left open for individual treatment? Whatever solution may be offered, it cannot be found in any rules of causation, despite the narrow theology found in the opinions of the court. ${ }^{46}$

"Gay v. State, 90 Tenn. 645, I8 S. W. 260 (I89I), SAYRE, op. cit. supra note 22, at I88, BEAIE, op. cit. sipra note 22 , at 349 .

4 Farley v. Crystal Coal \& Coke Co., 85 W. Va. 595, 102 S. E. 265, 9 A. L. R. 933 (1920); Mitchell Realty Co. v. West Allis, 184 Wis. 352, I99 N. W. 390 (I924), 35 A. L. R. 396 (1925). There are many interesting cases collected in the A. L. R. notes.

${ }^{2}$ Notes (1920) 9 A. L. R. 944 ; (1925) 35 A. L. R. 4II.

${ }^{46}$ Both the West Virginia and Wisconsin courts turn their decisions on the distinction between consequential and direct injury. (1920) 29 YALE L. J. 935: (1904) 4 CoL. L. REv. 367 ; (1920) 27 W. VA. L. Q. 200. 
The most extensive and most difficult class of crime cases with which the courts deal in terms of causation are those in which a defendant, while violating a penal statute, incidentally and unintentionally kills some one. The courts were quick to say that if a defendant, while doing an unlawful act, kills another, he is responsible for some grade of homicide, as well as for damages. As long as the unlawful act is a serious offense, this rough rule works fairly well. But when the unlawful act involves a minor police regulation, the rule does not work so well. And despite the employment of other rough devices as malum in se, malum prohibitum and negligence per se, the difficulties still persist.

Potter v. State ${ }^{47}$ is illustrative of hundreds of such cases. The defendant was carrying a concealed weapon in violation of a statute. He and $X$ became engaged in a friendly scuffle, the pistol was discharged, and $X$ was killed. The Supreme Court of Indiana reversed a conviction of involuntary manslaughter. ' The court correctly stated the question:

". . . did carrying the weapon unlawfully at the time of the homicide . . . render the accused guilty of the crime of involuntary manslaughter as charged in the indictment?" 48

The statute defining manslaughter was as follows:

"Whoever unlawfully kills any human being without malice, express or implied, either voluntarily upon a sudden heat, or involuntarily but in the commission of some unlawful act, is guilty of manslaughter. . . ."49

Ignoring the question-begging word "unlawfully" in the first clause, the court was caught here in the words of the statute. The defendant was doing an unlawful act in carrying a concealed weapon and a bullet from that very weapon killed the deceased. But instead of working out an adjustment between the two statutes involved, the court translated its problem into terms of causa-

${ }^{17} 162$ Ind. 213, 70 N. E. 129, 64 L. R. A. 942 (1904), SAYRE, op. cit. supra note 22 , at 177 ; $c f$. State v. Trollinger, 162 N. C. 618,77 S. E. 957, I L. R. A. (N. S.) 991 (ror3).

${ }^{2}$ Supra note 47 , at 215, 70 N. E. at I30.

${ }^{\circ}$ Ind. Ann. Stat. (Burns, I926) § 2416 . 
tion. It does this by a rhetorical question and answer about a different case. It says :

"If appellant, instead of carrying the pistol in question concealed, had been hunting with the weapon on Sunday in violation of the above statute, and when so hunting he had accidentally discharged it and killed Garnett, who happened to be standing near by, could it, in reason be asserted that his death was due to appellant's unlawful act of hunting on Sunday? Certainly not." 50

Passing over the doubtful answer the court gave to its own question, it continues :

"With equal reason and force it may be asserted that the mere fact that the accused was unlawfully carrying the weapon in question at the time it was accidentally discharged is not, under the circumstances, a material element in the case, for it is manifest that such unlawful act did not, during the scuffle between the parties, render the pistol any more liable to be discharged than though the carrying thereof had been lawful." 51

And thus the court most ingenuously eliminated the significance of the most material cause factor in the case. This method of refusing to deal with the case before it by substituting a different case is one of the most usual devices employed by judges. It is likewise the most deceptive and in the long run the most hurtful. Try as it could, the court could not honestly get rid of the case as it happened. The defendant was carrying a concealed weapon and, while doing that act, the weapon he was carrying in violation of law produced the death of the third party. What might have been done if the Sunday law had been violated, or what might have been done had the weapon been lawfully carried were not even pertinent arguments on the question of causal relation. They may or may not have been pertinent to the question of responsibility. The important thing about the decision in this case is that the defendant was held not responsible. After all, this was the question that the court was attempting to solve.

${ }^{50}$ Sispra note 47 , at $217,70 \mathrm{~N}$. E. at 131 .

si Sispra note 47 , at 217,70 N. E. at I3I. 
In a case before the North Carolina court ${ }^{52}$ two years later, the defendant was charged with manslaughter for killing $X$, whom he mistook for a turkey. The basis of the charge was the unlawful act of hunting on land without a license. The court held the defendant not guilty as the statute he violated was mahum prohibitum and not malum in se. It avoided the difficulties of proximate cause. Incidentally the court, in two or three sentences, said that the hunting statute was not designed to prevent homicide.

The Vermont court ${ }^{53}$ recently held the defendant responsible to the plaintiff for the accidental shooting of the plaintiff while both were hunting on Sunday. The court found sufficient basis of responsibility in the unlawful act of hunting on Sunday. The same court some years previous held that a plaintiff could not recover under an accident policy for an injury received by slipping on plowed ground while returning from a hunting expedition on Sunday. The policy exempted the insurer from liability in case of a violation of law ${ }^{54}$ and the plaintiff had violated the statute both as to hunting and as to traveling on Sunday.

Few courts are so literal as the Vermont court, for in many other hard cases in which defendants have been prosecuted for homicide on the basis of having killed a person accidentally while violating some police regulation, ${ }^{55}$ or in which recoveries have been sought under accident policies exempting the insurance company from liability if the insured was engaged in an unlawful act at the time of his injury, ${ }^{56}$ or in suits for damages in which defendants have sought to invoke the violation of some statute as

22 State v. Horton, 139 N. C. 588, 5I S. E. 945 (I905) ; cf. Comm. v. Adams, 114 Mass. 323 (1873).

White v. Levarn, 93 Vt. 218, 108 Atl. 564, II A. L. R. I219 (I918), WIISON, CASES ON TORTS (I928) 338.

${ }^{4}$ Duran v. Standard Life \& Accident Ins. Co., 63 Vt. 437, 22 Atl. 530, I3 L. R. A. 637 (189I) ; cf. Dervin v. Frenier, 9I Vt. 398, 100 Atl. 760 (1917), WIIsoN, op. cit. supra note 53 , at 342 (in which it was held that the defendant's driving without a license was a mere condition and not a cause of the hurt of the plaintiff who was run over).

${ }^{\infty}$ Dixon v. State, I04 Miss. 410, 6I So. 423, 45 L. R. A. (N. S.) 219 (1913); State v. Budge, I26 Me. 223, I37 Atl. 244, 53 A. L. R. 241 (1927) ; People v. Campbell, 237 Mich. 424, 212 N. W. 97 (1927) (contributory negligence).

${ }^{c 0}$ Townsend v. Commercial Traveler's Mutual Accident Ass'n, 231 N. Y. I48, I3I N. E. 87I, I7 A. L. R. I001, I005 (I92I). 
contributory negligence on the plaintiff's part, ${ }^{57}$ the courts have escaped from the difficulties of the situations by finding a lack of proximate cause.

Probably the most usual type of this group of cases is found in the harms done by automobile drivers operating cars with defective lights, at an excessive speed, without car or driver's license, on the left-hand side of the road, while intoxicated, transporting liquor, or in disregard of traffic signals or some other of the many regulations. If death results to the injured party, in most cases the defendant falls squarely within the manslaughter statute, ${ }^{58}$ as well as within the negligence per se doctrine. Despite the numerous pronouncements to the effect that the defendant is responsible because he was engaged in unlawful conduct at the time, in the hard cases the courts find the usual means of avoiding these rules. The favorite escape is found in "proximate cause." 59 But the North Carolina court, as in the hunting case, again suggests a qualification of the rule which would seem worthy of greater emphasis. It says :

"It is generally held that where one is engaged in an unlaw ful and dangerous act, which is itself in violation of a statute intended and designed to prevent injury to the person, and death ensues as a consequence thereof, the actor is guilty of manslaughter.

${ }^{57}$ Gilman v. Central Vt. Ry., 93 Vt. 340, 107 Atl. I22, I6 A. L. R. I102, I 108 (1919); Marland Refining Co. v. Duffy, 94 Okla. 16, 220 Pac. 846, 35 A. L. R. 52,62 (I923) ; Newcomb v. Boston Protective Dept., I46 Mass. 596, I6 N. E. 555 (1888) ; Speight v. Simonsen, II5 Ore. 618, 239 Pac. 542 (I925), 43 A. L. R. I I 49, II 53 (I926); Hansen v. Kemmish, 201 Iowa 1008, 208 N. W. 277, 45 A. L. R. 498 (I926).

ss People v. Cunningham, 64 Cal. App. I2, 220 Pac. 312 (1923); McDaniel v. State, ro5 Tex. Cr. App. 468, 288 S. W. I08I (1926); People v. Harris, 214 Mich. 145,182 N. W. 673,16 A. L. R. 9I0, 9I4 (Ig2I) ; $c f$. what this court says in People v. Townsend, 214 Mich. 267, 183 N. W. 177, I6 A. L. R. 902 (1921).

${ }^{50}$ Jackson v. State, IoI Ohio 152, 127 N. E. 870 (1920); People v. Barnes, I82 Mich. I79, 148 N. W. 400 (1914); Note (1918) L. R. A. I9I8B 954; Howell v. State, I30 N. E. 492 (Ind. I928); Mimmel v. State, I98 Ind. 444,154 N. E. I6 (I926); Gilman v. Central Vt. Ry., supra note 57; Statei v. Budge, sipra note 55 ; Notes (1925) 38 A. L. R. 1038; (1926) 43 A. L. R. II53; also cases supra note 47.

${ }^{\infty}$ State v. Whaley, I91 N. C. 387, 390, 132 S. E. 6,8 (1926). The italics are the writer's. Cf. State v. Kline, I68 Minn. 263, 209 N. W. 88I (I926); People v. Townsend, 214 Mich. 267,183 N. W. 177, I6 A. L. R. 902 (I92I); Note (1923) 27 A. L. R. II80. 
This distinction eliminates many cases. Sunday laws, licenses for cars, prohibitions against profane language and transporting intoxicants, parking regulations, and many others are probably not directed against physical violence. On the other hand, speed laws, requirements as to lights and brakes, prohibitions of driving while intoxicated, and others do have the safety of the person in view. The New York Court of Áppeals, in a case involving the violation of one of the health regulations which was relied on as a defense to an accident policy, has recently taken the same ground. "The Health Law was not intended to provide protection to insurance companies," it said. ${ }^{\text {} 1}$ The same idea is gaining wider and wider acceptance generally. ${ }^{62}$ This is but a recognition of the fact that rules of law, statutory and otherwise, in so far as they have any validity, have, or should have, purposes back of them, and are probably best understood in the light of the functions they are supposed to perform, however hard it may be to define them.

But even this distinction, while a most valuable one, does not always make perfectly clear just what judgment should be reached in numerous hard cases. Suppose a speed law of six miles per hour, and that the defendant is driving seven, when a little child darts out in front of his car and is killed. Or take the case of the concealed weapon which is accidentally discharged. Clearly both these rules are designed to protect life, and life has been taken as a result, at least in part, of the violation of both. Most courts refuse to reach the apparently logical conclusion, and rightly so. Here a fact is driven home which we consistently refuse to accept. Rules cannot be made which will take the place of judgment, and the refusal to accept this fact compels judges to invent all sorts of devices by which to escape. Rules will carry those who must pass judgment only so far, figuratively speaking, into the neighborhood of the problem to be passed upon, and then the judges

ar Supre note 56, at 155, 13I N. E. at 873 ; Corbett v. Scott, 243 N. Y. 66, 152 N. E. 467,46 A. L. R. 1064 (1926).

* Shelden v. Wichita R. R. \& L. Co., I25 Kan. 476, 264 Pac. 732 (I928); Boronkay v. Robinson \& Carpenter, 247 N. Y. 365 , I60 N. E. 400 (1928), WIIsoN, op. cit. supra note 53, at 240; (1928) 38 YALE L. J. 124; and see extended discussion of Peaslee, C. J., in Johnson v. Boston \& M. R. R., I43 Atl. 5I6 (N. H. 1928). 
must get off and walk. The clear cases do not require rules. Even laymen can decide easy cases. Nevertheless it is in these that most of our rules find their parentage. We have them in abundance where we need them least. But in hard cases, rules or no rules, courts cannot escape a decision. It is frequently difficult in these cases to narrow, in terms of any generalization, the questions to be decided, and it is a false notion to think that the judicial process requires that this be done. Rules are a means to an end, and it is as important to know when they give no aid as when they aid. And while it is true that to trust to judgment alone will result in neither uniformity of judgment nor uniformity of expression, it is also true that neither should be expected or desired. Any uniformity that rules seem to give in either respect is illusory. The factors which control judgment here are at large. If I could believe that judges were resorting to "proximate cause" merely to save their faces in these cases, I should have a great deal of admiration for their ingenuity. But no one can read many of the opinions in which this doctrine is given a place without feeling that many judges give to it the same sanctity that young children give to Santa Claus.

My only suggestion here is that the judicial process, in all except the plainest cases, should be left as free of restrictions as possible. It is made up of judge and jury who have the guidance of general formulas in terms of statutes and broad common law rules. These formulas are primarily useful for stating the question to be solved in the particular case. However aptly or inaptly it may serve the function, some formula must be employed for this purpose. Then a concurrence of judgment both of judge and jury is required before the defendant is required to pay. In turn, this judgment is articulated in terms of deductions made from the formulas employed in stating the question. But this articulation in most cases is exceedingly poor. The courts seem unable to rise above the distressingly inadequate and excessively used terminology of medieval morality. The legal theory on which the administration of both crimes and torts depends is wretchedly inadequate. Legal scholarship has no more exacting obligation than at this point. And the hopeless thing about it all is that legal 
scholarship seems primarily interested only in resuscitating what is already dead. The hope that the judgments of judges and juries could be subjected to control through smooth phrases was probably the lawyer's first dream. It is apparently one that he cannot forget. And, doubtless, the story of the development of legal science through these centuries of word-serfdom will be as hard to believe as that some of the other sciences found their way up through sorcery and alchemy and astrology.

Two recent cases illustrate the hopelessness of changing the emphasis from legal theology to one of rational judgment. In Henningsen $v$. Markowitz ${ }^{63}$ the defendant had sold a I3-year-old boy an air rifle in violation of a statute. The boy's mother sent him back with the rifle, but the defendant would not accept it. The mother then took the rifle and hid it. This was in December. The following June the boy and a companion found the gun and the companion was shooting it at a target when the plaintiff, an infant, received the shot in his eye. The defendant was convicted for the violation of the statute. In addition the plaintiff recovered $\$ 20,000$ damages against the defendant. The court in its opinion resolved the problem of the defendant's responsibility into one of proximate cause. But before it launched into that discussion, it made this interesting introductory holding:

"The legislative purpose in enacting these sections of the Penal Law is manifest. It was to prevent just such an occurrence as here happened." 64

What else was there to decide? It would be thought that, having found that the defendant violated his duty under a positive law made for the protection of the plaintiff against the very sort of risk that had caused him hurt, the court would have been satisfied. But not so. It still felt that there was an issue of proximate cause to be passed upon, although the defendant's conduct as a material factor in the result was as clear as the statement of facts could make it. Let the court tell its own story:

\footnotetext{
${ }^{\infty}$ I32 Misc. 547, 230 N. Y. Supp. 313 (1928).

ib Ibid. 548, 549, 230 N. Y. Supp. at 3I4.
} 
"The most serious question presented, however, is whether or not the conduct of Richard's mother does, as a matter of law, rescue defendant. It is urged that the possession by Mrs. Kevans, being a legal possession, brought to an end the incidence and effect of defendant's tort. It is intimated that while defendant would have been liable if the gun had been merely laid aside and after a period of 6 months used by these boys, Mrs. Kevans' possession during that period of time required an additional act on the part of Richard to bring it again into his possession, and that the force of causation was thereby broken. . . . The conclusion of Professor Beale (33 Harv. Law Rev. 633, 65I) has been frequently cited as a concise statement of a governing rule, viz.: 'On the other hand, where defendant's active force has come to rest in a position of apparent safety, the court will follow it no longer; if some new force later combines with this condition to create harm, the result is remote from defendant's act.'

"Here in my judgment the active force did not in legal contemplation come to rest. Defendant's wrongdoing continued to be potentially active so long and whenever the infant purchaser obtained access to the dangerous implement, constituting in itself a force which defendant had set in motion." 65

There are many significant things about this case. First, let me say that I concede that if any one can successfully formulate workable rules of causation, it is Professor Beale. But Professor Beale cannot insure what judges will do with his rules after he has formulated them. I am of the opinion that Professor Beale would not stand for any such use of his rule as was made in this case, for in the same article from which the rule is quoted by the court, and in talking about the very same cases as the type here involved, he says :

"It is to be noticed, that if the explosive gets into the hands of an adult the defendant's force has ceased to be an active danger; if the explosive thereafter gets into the hands

${ }^{\infty}$ Ibid. 549, 550, 230 N. Y. Supp. at 315. The italics are the writer's. 
of a child, defendant is not the proximate cause of anything this child may do with it." 66

In short, if the taking of this gun by the mother and keeping it in successful seclusion for six months was not a "coming to rest in a position of apparent safety," whereupon the defendant's conduct "ceased to be an active danger," it would be impossible to imagine one. If Professor Beale's rule means anything it means that the defendant was not the proximate cause in this case. The court felt that the rule did mean something, but it also felt that the plaintiff should recover. Therefore it resorted to the same judicial magic which has been resorted to in hundreds of cases, when it said "the active force did not in legal contemplation come to rest," and that it continued to be "potentially active." This merely means that the rule can be stretched to mean what the courts may want it to mean. But these terms of elastic fiction completely destroy the integrity of the rule itself. Such has been the shabby fate of every rule of causation which has been formulated.

But the judgment is a most acceptable one, from my point of view at least, and was sufficiently justified when the court decided that the defendant had violated a statute made to protect the plaintiff from just the sort of thing that had happened to him. All the remaining talk is merely the result of the bad habits of the judiciary generally. Fortunately the judgment of the particular judge was stout enough to wreck a rule while seeming to accept it. Many other judges might have surrendered before such authority.

In Johnson v. Boston \& Maine R. $R .^{67}$ the New Hampshire court delivered one of the most interesting decisions of the year. There was a collision between the defendant's train and the plaintiff's automobile at a crossing. A statute provided that: "No person shall operate a motor vehicle upon any way in this state unless licensed." ${ }^{8}$ The plaintiff had no license and was non-

${ }^{\circ}$ Beale, The Proximate Consequences of an Act (1920) 33 HARV. L. REV. 633,656

" I43 Atl. 516 (N. H. I928).

*Ibid. 517. 
suited on the ground that, being a wrongdoer himself, he could not maintain suit against the defendant for its negligence.

Quite unlike most courts, the New Hampshire court quickly conceded that there was no lack of causal relation. ${ }^{69}$ On the other hand it recognized that the question was a far more significant one. It said:

"The question thus raised is not really one of causation. It is evident that the plaintiff's act of driving the car was causal. . . . The issue here is whether the law makes the plaintiff accountable for such causation. . . . The whole matter resolves itself into a question of legislative intent." 70

In discovery of the legislative purpose, the court said:

"It is self-evident that the chief object of the statute is to protect other users of the highways. ${ }^{71}$. . . The moving purpose was the protection of travelers. ${ }^{72}$. . The reason for this prohibition is that driving by the unfit is dangerous. . . Moreover, it is matter of common knowledge that more rather than less restriction upon motor vehicle operation is needed for the protection of the traveling public. ${ }^{73}$ The plaintiff's act in driving without a license is a wrong against third parties because the legislature has so provided." 74

Thus the court declined to allow the plaintiff to recover for the negligence of the defendant because of the plaintiff's own wrong. It looks like irrefutable logic based on sound premises. And it is possible that the court's judgment coincided with what it

so "The argument that lack of license is not causal and that therefore the violation is immaterial ignores the terms of the statute, puts the facts upon which the prohibition depends in the place of the things prohibited, and thus reaches a conclusion based upon false premises." Ibid. 52r. "The Plaintiff's act of operating a car was causal in the strictest sense. It was not his mere presence on the highway, but his operation of the car, which brought him into the collision." Ibid. 523 .
${ }^{70}$ Ibid. 521, 523.
${ }^{71}$ Ibid. 517 .
I2 Ibid. 523 .
Ibid. 522.
${ }^{71}$ Ibid. 523 . 
considered to be the legislative judgment. But, assuming that the court only reached such a judgment because it felt impelled by the legislative judgment to do so, did it not stop short in its inquiry into the "legislative intent"? Let what I have already said be repeated here. The statement of the problem in terms of the purpose of the rule does not necessarily make it easy of solution. It does make the problem more graspable and hence more rational. The statute was doubtless designed, as the court says, to furnish other travelers on the highway the protection indicated. But was it designed to protect railroads from their negligence at crossings? To put it differently, was the court's minor premise correct that the train at the crossing was a traveler in terms of its major premise? It is true that in one sense the train of the defendant in crossing the highway was a traveler on the highway, but would the legislature have ever considered such a statute for the protection of railways? Was this sort of collision among the hazards at which the statute was directed? And would the court have been going far afield to have limited the plaintiff's duty under the statute to the general pedestrian and vehicular traffic of the highway? It may well be that the court in this case successfully eluded the pitfall of proximate cause to be caught in one of the logical snares involved in determining the "legislative intent." Possibly also the court, in its efforts to determine the scope of the statute, failed to consider other factors of more importance.

Allow me to make the point again that the general rule, whether it is your general rule or mine, is dangerous. Judges frequently insist on riding a general rule to the bitter end. If a plaintiff be guilty of contributory negligence by violation of a statute in one case, as against one person, he is in all cases, whether the statute was designed to cover that case or not. Judges must have universals and absolutes. Such is and has been the mournful state of legal theology. And, when the judicial process is so indoctrinated, a good general rule, as well as a poor one, may be made to do hurt. The only antidote lies in a revolt from the supremacy of rules. 


\section{Judgment Hampered by Rules of Causation}

Are there any differences between the rules of causation in crimes and in torts? Such an inquiry has little place in any system of legal theory which deserves respect. First, there are no rules of causal relation used or required in any legitimate sense of that term, either in torts or crimes. Causal relation can be reduced to no lower terms. Second, in determining the extremes of legal protection-the problem which is hidden under the causation terminology - the sweep of judgment quickly passes beyond the reach of any rules that can be framed. And what is more, the judicial process in these cases ought to be left free of hampering restraints in fixing the limits of protection in the particular case. If there is to be any rule, this rule of freedom of judgment should be the rule both in torts and crimes. It is all that we have to depend upon. But rules or no rules, the bounds of legal protection are hard to draw. In one case. it may make the factors that should control judgment clearer to state the problem as one of statutory construction, legislative intent, interpretation; in others it may look easier to state the problem in terms of ends and functions; in still others, where the lines are drawn the closest perhaps, all that a court can do is to focus attention upon the very risk in question and ask whether it should be placed upon the one party or the other. In the clear, easy cases, where the path has been marked time and time again, it is well enough to consider these problems in terms of "rights and duties." Certainly some such stabilized symbolism as the last is desirable wherever judgment can be made automatic or even nearly so. But in no instance has a place been found for rules of causation. The phraseology of causation has been found to lend itself to learned dissertation about any situation which the judges do not understand. It has never afforded a glimmer of light on any problem a court has had to decide, nor does it provide the slightest articulation for any judgments courts have passed. It has served but one useful function, and that has been to give the judges a dependable way out of difficult situations when they have made up their minds but either do not know how, or else do not take the time, to articulate their conclusions on a rational basis. Judging from the use that 
has been made of it, it has served this function well. There is little probability that the courts will knowingly surrender such a useful and safe means of escape.

It may be objected that, conceding all that has been said, the problem, which is usually considered under terms of causation, is not solved when it has been translated into other forms of statement. That is a valid observation. And what is more, nothing can be done about it. No one has yet succeeded in making any word scheme do the service of judgment on any large scale. Nor has any one isolated and reduced to control the factors which direct and control judgment in general. Nothing is clearer than that these factors differ from case to case, even in torts, as well as in crimes, and vary even more from torts to crimes. There are frequently difficulties of administration on the criminal side of the docket where there are none on the civil side, or vice versa. Economic considerations may weigh heavily on one side or the other. Ethical influences may and do fluctuate from case to case. The risk itself may be one so unusual that there is no need of a strict responsibility generally, but in the particular case may be so exacting that the defendant should pay both the penalty and the damages. I am of the opinion that courts, first and last, sense these factors, even though vaguely at times, and even though the thick mists of their terminology are hard to penetrate. ${ }^{75}$ But I insist that they need to be brought out into the open and talked about in as plain terms as can be employed. Though it may be conceded that somehow or other the judicial process gets an unbelievably large amount of its work done acceptably, there is no possibility of its successfully meeting the exactions of hard cases until it is recognized that the judge, in finding a basis for judgment, must go beyond and above any range for which rules have yet been fash-

ro "The moral element (Derosier v. New England Tel. \& Tel. Co., supra [8I N. H. 45I, I30 Atl. I45 (1925)] ) and the inherent justice, sometimes called reasonableness (Cavanaugh v. Railroad, 76 N. H. 68, 79 A. 694 [19II] ; McCaffrey v. Concord Electric Co., 80 N. H. 45, 52, II4 A. 395, I7 A. L. R. 8I3 [I92I]; Stanley v. Kimball, 80 N. H. 43I, 433, II8 A. 636 [I9z2] ; Tullgren v. Company, 82 N. H. $268,271,133$ A. 4 [1926]), of the imposition of accountability, have often been the controlling factors." Ibid. 521.

See my article on The Duty Problem in Negligence Cases, supra note 20 , in which I have attempted to identify the more important factors which control the judgment of courts. 
ioned. This does not mean that the individual judge cannot learn much from what other judges in other cases have done and said, or that juries cannot be aided by intelligent instructions. These may still be pressed; they are valuable means of educating judgment, but that is as much as they can do in these hard cases. Neither good administration nor the progress of law at this point lies in authority of any sort. Legal science needs rather the power to discern the factors at work in the particular case, and the power to pass acceptable judgments for the time and place. These powers are not developed except by their employment. They have been in large part effectually blocked by so-called rules of causation, and thus, in addition to being worthless, these rules are hurtful. 